\title{
JUNG'S PSYCHOLOGICAL TYPES AND CHARACTERISATION IN ALEX LAGUMA'S LITERARY WORKS
}

\author{
${ }^{1}$ Issa Omotosho Garuba* \\ ${ }^{1}$ Kwara State University, Nigeria \\ *Corresponding Author: omotoshoissa@gmail.com.
}

\begin{abstract}
Characterisation has immense influence on the study of literature, because it is as one of the determinants in measuring the quality of a narrative. Thus, in assessing this aspect of a narrative, especially when dealing with characters in a racist narrative, requires an encompassing analytical approach. Hence, this paper is aimed at analysing the psychological impulses that underlying the personality formations of the black characters in Alex La Guma's A Walk in the Night and In the Fog of the Season's End. In which, it adopts Carl Gustav Jung's Psychological Types. The choice of this psychoanalytical tool is informed by the fact that, of all the psychological discoveries of Jung, the psychological types or the psychology of individuation has been acknowledged as his most significant discovery in psychoanalysis which has not attracted the literary critical attention, especially in terms of character analysis. To this end, therefore, the study attempts to establish the two categories of the reactions identified by Jung, namely introversion and extraversion, using the two Alex La Guma's fictions.In addition, through the psychological complexities of the characters, ultimately, it is revealed that the extreme reactions are the products of individual innate tendencies, devoid of the social or the racial affiliations.
\end{abstract}

Keywords: Psychoanalysis; Jung; Psychological Types; Characterisation;Narrative; LaGuma

\begin{abstract}
ABSTRAK
Karakterisasi sendiri memiliki pengaruh yang sangat besar pada sebuah studi literatur, karena itu dianggap sebagai salah satu penentu utama dalam mengukur kualitas sebuah narasi. Jadi, dalam menilai aspek narasi seperti ini, terutama ketika berhadapan dengan tokoh-tokoh atau karakterisasi dalam sebuah narasi rasis, sehingga memerlukan pendekatan analitis yang sangat menyeluruh. Oleh karena itu, makalah ini sendiri bertujuan untuk dapat menganalisis sebuah impuls psikologis sehingga hal tersebut mendasari sebuah pembentukan kepribadian seorang karakter berkulit hitam di dalam A Walk in the Night dan In the Fog of the Season's End karya Alex La Guma. Di mana, ia mengadopsi jenis psikologis yang dikemukakan oleh seorang Carl Gustav Jung. Pilihan alat psikoanalisis ini sendiri diinformasikan oleh fakta bahwa, dari semua penemuan psikologis Jung, tipe psikologis atau psikologi individuasi telah diakui sebagai penemuannya yang paling signifikan dalam psikoanalisis yang belum menarik perhatian kritis sastra, terutama dalam hal analisis karakter. Untuk tujuan ini, oleh karena itu, penelitian ini berupaya untuk menetapkan dua kategori reaksi yang diidentifikasi oleh Jung, yaitu introversi dan juga extraversion, dimana keduanya menggunakan dua fiksi karya Alex La Guma. Selain itu, melalui kompleksitas sebuah psikologis karakter, akhirnya, terungkap bahwa reaksi ekstrem adalah produk dari kecenderungan bawaan individu, tanpa adanya afiliasi sosial atau rasial.
\end{abstract}

Kata kunci: Psikoanalisis; Jung; Tipe Psikososial; Karakteriasi; Narasi; La Guma

\section{INTRODUCTION}

The centrality of characterisation and/or character in narrative cannot be overemphasized because it is intrinsic to "stylistic and narrative techniques for the 
Celtic: A Journal of Culture, English Language Teaching, Literature and Linguistics

Vol. 7, No. 1, June 2020.

E-ISSN: 2621-9158 P-ISSN:2356-0401

http://ejournal.umm.ac.id/index.php/celtic/index

representation of human features, actions, intentions, desires and traits in the novel form and how these interact with reader's cognitive strategies forrecognising and developing knowledge...about other people" (Martin, 2004, p. 10). The manifestations of these human features are presented by the novelist through characters who are made to exhibit these various traits. If the story seems 'true to life', for instance, readers generally realise that "its characters act in a reasonably consistent manner and that the author has provided them with motivation: sufficient reason to behave as they do" (Kennedy \&Gioia, 2007, p. 73). This realisation inevitably places characters at the centre of a narrative, that is, as the collective force by which the plot is driven. In specific terms,Bennett\&Royle (2004, p. 60) accentuate this key placeof characters inliterary texts as "the life of literature: they are the objects of our curiosity and fascination, affection and dislike, admiration and condemnation". Similarly, Stevick(1967, p. 221) observes that "through the nineteenth century, until well into the twentieth century, the fashionable way of responding to a novel was to consider its characters, to analyze their motives, to remark on the cleverness of their portrayal, and quite often to declare one's love for them". Apparently, all of these are critical pointers to the centrality of characters to narrative and its criticism. In view of this, Stevick(1967, p. 222) further maintains that:

...whether criticism of character is fashionable or not, whether the bulk of criticism that deals with character is incisive or fatuous, individual readers will continue to respond to novels because their sense of common humanity is engaged by the portrayals of human beings which they find there.

Thus, bearing in mind that psychoanalysis is a critical method by which characters' dispositions can be analysed in relation to motivating factors or influences, this study examines the probable psychological impulses underlying the personality formations of the black characters in Alex La Guma's $A$ Walk in the Night(1962) and In the Fog of the Season's End(1972).Primarily, the study assesses the articulation of the characters' most private anxieties vis-a-vis meanings held to culture and race by which their personality types are definable, and offers a perspective on them as individual's unconscious idiosyncrasies largely ignited by socio-cultural phenomena. Thisultimately corroborates the assertion that "reading characters involves learning to acknowledge that a person can never finally be singular - that there is always multiplicity, ambiguity, otherness and unconsciousness." (Bennett \&Royle, 2004, p. 67)

\section{METHOD}

This paper is a product of a qualitative research design. A research designis acknowledged as "the researcher's plan of how to proceed to gain an understanding of some groups or some phenomena in their natural settings" (Ary et al., 2010 cited in Azizah\&Sudiran, 2015, p. 7).Qualitative research is defined as involving an interpretative and naturalistic approach (Denzin\& Lincoln, 1994, p. 3). This implies that qualitative researchers "study things in their natural settings, attempting to make sense of, or to interpret phenomena in terms of the meanings people bring to them" (3). It is a kind of study that is characteristically aimed at understanding some aspects of social life and its methods (in general) to generate words, rather than numbers, as data for analysis 
(Patton \&Cochron, 2002, p. 23). Qualitative research method is relevant to this kind of research because, in the words of Babbie\&Mouton (2001, p. 7), it entailsthe "generation of contextually valid descriptions and interpretations of human actions based on indepth inside reconstructions of the life of the worlds of actors".

The data presentation in the study has been undertaken by drawing on critical actions (conscious and unconscious), reactions and words of the major characters in the objects of the research, the two selected novels of Alex La Guma, $A$ Walk in the Night and In the Fog of the Season's End.LaGuma was a South African writer who wrote substantially against the background of the erstwhile ApartheidSouth Africa, and the two novelsindeed insightfully provide such a historical context. In order to provide psychological response tothe researchquery, the study adopts Jung's Psychological Types, otherwise known as the theory of individuation, as the critical tool. The suitability of the theory to character study in these racial narratives, and indeed other novels of similar intense focus on character identity and psychological configuration at large, is underscored by the fact that it provides an in-depth psychological approach to how human personalities or characters that are oriented in particular ways based on their reactions to, or relations with, the realities of their immediate environments upon which their personalities are, in turn, categorised or identifiable in terms of types. Also, alongside this framework, the study contextualizes what is conceived as personality formation in Apartheid South Africa vis-à-vis La Guma'sfiction. This is with a view to putting in perspectives the probable psychological dispositions within which the characters in La Guma's fiction, who are largely products of the notorious system, are examinable.

\section{Jung's Psychological Types}

Although theories of personality abound, Carl Gustav Jung offers a distinctively outstanding theory of personality formation which can, indeed, "be fully grasped especially when it is traced to, and placed within, the context of the general psychological theory of personality" (Garuba, 2019, p. 57).His personality theory is anchored on two basic personality orientations- introversion and extraversion - by means of which man is acknowledgeably organised. In view of this, it is presumed that certain psychological and perceptual functions and attitudes determine the ways in which man habitually or preferentially orient him/herself and, in turn, aid his/her conception of phenomenological experience (Jung, 1946, pp. 183-184). He locates his observation historically thus:

When we reflect upon human history, we know how the destinies of one individual are conditioned more by the objects of his interest, while in another they are conditioned more by his own inner self, by his subject. Since, therefore, we all swerve rather more towards one side than the other, we are naturally disposed to understand everything in the sense of our own type. (Jung, 1946, p.9)

The foregoing apparently entails a prelude to Jung's typology or classification of human psychological orientations. Thus, a type (either extravert or introvert) is said to exist when an individual exhibits the operation of one or the other of the personality 
Celtic: A Journal of Culture, English Language Teaching, Literature and Linguistics

Vol. 7, No. 1, June 2020.

E-ISSN: 2621-9158 P-ISSN:2356-0401

http://ejournal.umm.ac.id/index.php/celtic/index

inclinations more. He notes emphatically that it is "the individual disposition which decides whether one belongs to this or that type" (Jung, 1946, p. 560). The two personality types are characteristically described as follows:

Introversion is normally characterized by a hesitant, reflective, retiring nature that keeps itself to itself, shrinks from objects, is always slightly on the defensive and prefers to hide behind mistrustful scrutiny. Extraversion is normally characterized by an outgoing, candid, and accommodating nature that adapts easily to a given situation, quickly forms attachments, and, setting aside any possible misgivings, will often venture forth with careless confidence into unknown situations. In the first case obviously the subject, and in the second the object, is all-important. (Jung, 1946, p.44)

His actual definitions of the two attitude-types are relatively simple. Extraversion means an "outward flowing of the libido" or "an orientation to the outer world of people, things and activities" while Introversion means the "inward-flow of the libido" or an "orientation to the inner world of concepts, ideas, and internal experience" (Mowah, 1996, p. 4; Sommers-Flanagan \&Sommers-Flanagan, 2004, p. 12). In other words, extraversion is the attitude style in which "external factors are the predominant motivating force for judgments, perceptions, feelings, affects and actions while introversion is where internal or subjective factors are the chief motivation"(Sharp, 1987, p. 14). That is, "while the extravert responds to what comes to the subject from the object (outer reality), the introvert relates mainly to the impressions aroused by the object in the subject (inner reality)" (Sharp, 1987, p. 65).

Jung's personality conceptions are, implicitly, theoretical principles which he has "abstracted from an abundance of observed facts". (Jung, 1946, p. 10). Whether it is due to biological or environmental inclinations, it is further revealed that every individual possesses both mechanisms but only the relative predominance of the one or the other in the individual determines the type (p.10). In his general description of the types and how they function in shaping human personality, he realizes that there is a natural tendency to regard such differences in human nature as mere idiosyncrasies. Thus, he posits that:

anyone with the opportunity of gaining a fundamental knowledge of many men will soon discover that such a far-reaching contrast does not merely concern the individual case, but is a question of typical attitudes, with a universality far greater than a limited psychological experience would at first assume. (p. 413)

In addition, it is established that both the basic attitudes described above are inherent in every individual. That is, no individual is only introvertedly or extravertedly inclined; rather, it is "always a relation of adaptation" (p. 414) whereby "only the relative predominance of the one or the other determines the type". (p. 10)

In his conception of the nature and distribution of the personality types, several observations are made by Jung. According to him, the two attitude-types are ubiquitous and affect all levels of society. In fact, they override the distinctions of sex, noting further that the types apparently have quite random distribution, such that, in the same 
family, two children may even be antithetical, i.e. "one is introverted, and another extraverted" (Jung, 1946, pp. 413-414). In view of this, in examining the possible origins of the attitude-types, he concludes that they do not arise from conscious selection or intention and must therefore be due to some unconscious, instinctive cause:

Since, in the light of these facts, the attitude-types, regarded as a general phenomenon having an apparent random distribution, can be no affair of conscious judgment or intention, its existence must be due to some unconscious, instinctive cause. The contrast of types, therefore, as a universal psychological phenomenon, must in some way or other have its biological precursor. (p. 414)

Finally, four basic operational and/or functional modes by which both personality attitudes are analytically ascertainable or identifiable in individuals are offered by Jung. The functions are: Thinking, Feeling, Sensation, and Intuition (p. 14). Thus, eight (8) variables are distinctly established for analyzing personality types: Extraverted Thinking Type; Extraverted Feeling Type; Extraverted Sensation Type; Extraverted Intuition Type; Introverted Thinking Type; Introverted Feeling Type; Introverted Sensation Type; and Introverted Intuition Type. (See Jung, 1946)

\section{Contextualising Personality Formation in Apartheid South Africa vis-à-vis Alex La Guma'sFiction}

It is axiomatic that Alex La Guma'sworks can be properly construed against the background of the historical apartheid in South Africa. Under the system, South Africa was a society said to have been built on "a vertical separation of races"; that is, whites from blacks (Davenport, 1987, p. 323). The reality of the racist South Africa apartheid era was a situation whereby to be black or non-white translated to an absolute personality negation (Starck-Adler, 2005 p. 94). It was "a colonial world of manicheism where the black man was regarded as the quintessential evil" (Ogbeide, 2014, p. 116).

Indeed, the atmosphere of racial injustice inflicted on the victims (the coloured peoples) by whites during apartheid characterises La Guma'snarratives.Nwagbara (2011, p. 115)posits that his fiction "constantly challenges and interrogates the conscience of apartheid, whose operational ethos is verged on violence". La Guma's identification with the marginalised blacks, who daily struggle, sometimes violently, against thedehumanising system assumes a crucial base of his fiction and, in the context of this study, the blacks in the struggle are presumably susceptible to personality reorientations and/or formations owing to the effects of the apartheid system on their psyches. This especially so, considering the enormity of the various assaults on their sensibilities and the deplorable conditions to which they are subjected by settlers on their native land. It is such conditions that have, therefore, circumstantially transformed individual characters' psyches, hence new personalities, as critically observed in his works.

\section{FINDINGS AND DISCUSSION}

\section{Extraverted Feeling Type in $A$ Walk in the Night}

The setting of the novella, a rotten crime-ridden District Six, Cape Town, South Africa, where the entire blacks inhabit, unambiguously offers a social 
stratificationbetween the inferior blacks and the superior whites which characterised apartheid era in South Africa. The development thus generates a significant level of racial rift in their relations, particularly emanating from the marginalised blacks who have, as a result, turned violent and ruinous to themselves and the society at large.Ogbeide (2014, pp. 116-117) describes the setting of the text vis-à-vis the blacks' condition thus:

The world of District Six, as presented by La Guma, is one inhabited by spivs, whores, gangsters, poverty-stricken families and sundry social derelicts who are doomed by the apartheid system for a certain term to walk the night like Shakespeare's ghost. Hedged in by racial segregation, exploitation and lack of education and therefore, poor or no job at all, most of the coloured youths in District Six have come to see virtue in naked violence and the smoking of "dagga".

Indeed, the encounter between the major character in $A$ Walk in the Night, Micheal Adonis, and a white old man, Mr. Douhgty, speaks volume of the extent of hatred, disgust and inhumanity underlying the racial stereotypes, which is critically seen to have substantially informed a new personality formation in the protagonist, Micheal Adonis.

Micheal has just lost his job as a factory worker, via an outright disengagement, for daring to speak back at his white boss. On his way home, he nurses the situation which he considers to be apparently unjust, coupled with similar experiences of racial discrimination amidst the pool of which he is brought up. He encounters Mr. Doughty, who is known to him, and in the ensuing relations, he murders him, following an insignificant issue of a bottle of wine that is being shared (p. 27). To make a justifiable case for this murderous act would involve certain psychological (unconscious) underpinnings, if it cannot be construed consciously, as the case here. In other words, the justification for the brutal act is psychologically imperative. According to Pointer (2011, p. 19) "this individual act of violence is therapeutic... it frees Micheal from his inferiority complex and from his confusion and inaction". Indeed, following the killing, Micheal:

was suddenly pleased and proud of his own predicament. He felt as if he was the only man who had ever killed another and thought himself a curiosity at which people should wonder. He longed to be questioned about it, about the way he had felt when he had done it, about the impulse that had caused him to take the life of another. But the difficulty was that to reveal his secret was dangerous, so he had to carry it with him for all time or accept the consequences. The rights and wrongs of the matter did not occur to him then. It was just something that, to himself, placed him above others, like a poor beggar who suddenly found himself the heir to vast riches. (pp. 62-63)

On the other hand, the identity of Mr. Doughty is of great significance. Being a coloured South African, Micheal is remotely, at that moment, overtaken by a collective unconscious, in Jung's conception, by the distant past wherein 'white' as racial identity 
is already perceived an arch enemy, a situation that is orchestrated by the whites' unjust racial relations with them. This is immediately rekindled by the occasion of his presumed unjust disengagement from job. Hence, he is psychologically overwhelmed by the entire racist condition in which they have been overtly denigrated. He then becomes a new or another personality, at that moment, under the influence of the realities of his unconscious, leading to what can be considered as an unconscious revengeful act against his unconsciously perceived enemy (the white image in the old man), the killing of the old man over triviality. This unconscious impulse begins to exude in him at a point at which the old man helplessly demands at least a drop of wine from Micheal: "Micheal, my boy, spare a drop for your old uncle." Instead, Micheal replies angrily, "You old bastard... Can't a boy have a bloody piss without getting kicked in the backside by a lot of effing law?" (p. 26). Micheal's raging response is, of course, quite insightful of the stringent conditions under which they live, and which, in turn, becomes a source of psychological worries for them. Otherwise, the act would remain absolutely unjustifiable considering the helpless and pathetic way the narrator describes the old man, despite being white:

"God bless my soul, I've got my troubles, too," the old man said, with a sudden whine in his voice. "Here I am and nobody to look after an old man." Tears of remorse gathered in his pale, red-rimmed eyes, and he knuckled them with a tangled skein of dirty cord that was his hand. "Look at me. I used to be something in my days. God bless my soul, I used to be something." (p. 25)

In other words, Micheal would have shown some civility and pity, if not for his psychological imbalance and impatience. Evidently, Micheal demonstrates the unconscious drive underlying his act thus:

He stared back at the wreck on the bed and said, aloud, "God, I didn't mean it. I didn't mean to kill the blerry old man." He wiped his mouth on the back of his hand and tasted the wine on it, then rubbed it dry on the seat of his jeans. A flood of thought bubbled through his mind. There's going to be trouble. Didn't mean it. Better get out. The law don't like white people being finished off. Well, I didn't meant it. Better get out before somebody comes. I never been here. He looked at the sprawled figure that looked like a blowndown scarecrow. Well, he didn't have no right living here with us Coloreds. (pp. 27-28)

Placing the entire scenario within the theory of Jung, the personality inclination towards which Micheal Adonis is driven is ascertained as typical of an 'extraverted feeling' personality type. Generally, external or objective factors are said to be the predominant motivating force for judgment, feelings, perceptions and actions of every extravertedly inclined individual. In what he conceived as the problem of the attitudeattitude types in Two Essays in Analytical Psychology, Jung (1972, p. 62) attributes to such a personality "an outgoing, candid, and accommodating nature that adapts easily to a given situation, quickly forms attachments, and, setting aside any possible misgivings, will often ventures forth with careless confidence into unknown situations".

From the above general perspective, to start with, Micheal is perceived to have demonstrated this characteristic trend in his reaction to a white man's contempt for him 
Celtic: A Journal of Culture, English Language Teaching, Literature and Linguistics

Vol. 7, No. 1, June 2020.

E-ISSN: 2621-9158 P-ISSN:2356-0401

http://ejournal.umm.ac.id/index.php/celtic/index

while he (Micheal) uses a piss-room at work. It is the circumstance which leads to his disengagement from his job. Shortly after the incident, on his way home at a café, he bitterly and furiously relates it to a fellow black, Willie boy:

"Howzit," Micheal Adonis said, sitting down opposite to him. They were not very close friends, but had been thrown together in the whirlpool world of poverty, petty crime and violence of which that café was outpost.

"Nice boy, nice. You know me, mos. Always take it easy. How goes it with you?"

"Strolling again. Got pushed out of my job at the factory."

"How come then?"

"Answered back to a effing white rooker. Foreman."

"Those whites. What happened?"

"That white bastard was lucky I didn't pull him up good. He had been asking for a long time. Every time a man goes to the piss-house he starts moaning. Jesus Christ, the way he went on you think a man had to wet his pants rather than take a minute off. Well, he picked on me for going for a leak and I told him to go hell.” (pp. 3-4)

In the ensuing conversation, it is evident that the stringent laws of the land condition and forbid any coloured individual to engage, attack, or speak back at white in any form. Ordinarily, Micheal knows and ought to be conscious of this; by avoiding such an act, yet he dares it and even gets more angry and acrimonious after being fired consequentially. Typical of an extraverted orientation, it is an unknown situation, that is, the consequence of his act, which he has simply ventured into and now gets dejected over. This is revealed more after both have been served their meals: "Micheal Adonis went on eating, thinking over and over again, that sonavabitch, that bloody white sonavabitch, I'll get him. Anger seemed to make him ravenous and he bolted his food." (p. 5) At this point in time, the violent acrimony against a white figure has unconsciously taken more definite shape in him, and he goes on with it, as revealed in his repeated imagination of what he could or would do to the white man if runs into him.

From a specific perspective, ultimately, the 'feeling' part of his extraversion inclination gets into the picture, and this subsequently causes him to have impulsively killed that white old man after leaving the cafe, even when the man is not immediately connected to his current trouble. The impulse becomes more understood because, despite being harmless and helpless, the old man is in a way originally connected with the affective response currently being produced in him, typical of an extraverted feeling type, that of 'the traditional or generally accepted values' under the spell or impulse of which he is. Indeed, in Micheal's case, the collective value, belief or notion under which impulse he acts at that moment can be construed as the plain incompatibility and intolerability of their race with the whites. Presumably, they are two separate worlds that, on no account, should get along well owing to the racial segregation that has characterised the Apartheid era in their country. This, therefore, largely underlies the unconscious irresistibility of his murderous act against an individually innocent white man who, at some point, is said not to have had any advantage of the system even as a 
white man. In other words, it is caused by the unconscious aspect of his perception of his real world. Jung(1946, p. 23) says in this regard:

There are, moreover, unconscious aspects of our perception of reality. The first is the fact that even when our senses react to real phenomena, sights and sounds, they are somehow translated from the realm of reality into that of the mind. Within the mind they become psychic events whose ultimate nature is unknowable (for the psyche cannot know its own psychical substance).

Significantly, on a conclusive note, a clear distinction is made in the analysis between the conscious and unconscious realities of Micheal Adonis. The former, which is characterised by the contemptuous racial discrimination of the coloured by the whites, is revealed as the factor-impulse behind the latter, his violent acts. The imperative of this is asserted by Jung that it is the only way personality typology and/or classification can be analytically justifiable:

For the sake of understanding, it is, I think, a good thing to detach the man from his shadow, the unconscious; otherwise the discussion is threatened with unparalleled confusion of ideas. One sees much in another man which does not belong to his conscious psychology, but which gleams out from his unconscious, and one is rather tempted to regard the observed quality as belonging to this conscious ego. Life and fate may do this, but the psychologist, to whom the knowledge of the structure of the psyche and the dawning possibility of a better understanding of men is of the deepest concern, must not. A clear discrimination of the conscious man from his unconscious is imperative, since only the assimilation of conscious standpoints will clarity and understanding be gained, and never through a process of reduction to the unconscious backgrounds, sidelights, and quarter-tones. (pp. 203-204)

Indeed, that the human mind works at various levels presupposes that each part or level is distinctly observable and analysable in order to determine their operational interactions which, in turn, shape the general human psychical frame or structure, as asserted by Jung.

\section{Introverted Feeling Type in In the Fog of the Season's End}

In every society where injustice, in all its dimensions, is structurally and systematically inherent, there is greater propensity for activism or revolution by the oppressed group channelled towards upturning the situation. With specific reference to the historical apartheid in South Africa, there are substantial indices of activism or revolutionary bents in literary works about the racial imbalance of the period, ranging from liberal to violent ones, perpetrated by the segregated blacks. The works of Alex La Guma are evidently paradigmatic. According to Nwagbara (2011, p. 119), despite the criticisms that have been levelled against his works, La Guma's novels:

are steeped in unveiling the crisis period in the history of black-white contestation, which still casts long shadows in the contemporary time in South 
Africa. Beginning with $A$ Walk in the Night to Time of the Butcherbird, La guma's main concern is to portray how blacks try to bring an end to the capitalist motive as well as oppression behind the Great Trek, which was informed by the desire to expand the white man's economic coast through forceful acquisition of the indigenes' land for economic reasons.

The novel, In the Fog of the Season's End, more than the relatively mild scenario recorded in $A$ Walk in the Night, is an apparent exposition of a strand of violent activisms carried out by the oppressed blacks against white oppressors in the apartheid era. The background insight to this is immediately offered as the novel opens in the prologue. The prologue takes the reader4 through the experience of physical and psychological torture of a black, Tetwane, who have been arrested amongst others killed following a protest. He is being subjected to such tortuous experience because they want him to reveal the secret details of their underground activism as well the identities of others who escaped apprehension in the encounter. In spite of the extremely hot atmosphere, the prisoner insistently asserts:

'You want me to co-operate. You have shot my people when they have protested against unjust treatment; you have torn people from their homes, imprisoned them, not for stealing or murder, but for not having your permission to live. Our children live in rags and die of hunger. And you want me to co-operate with you? It is impossible.' (pp. 5-6)

The entire scenario is against the backdrop of the fact that a group of blacks consisting of the three main characters (Tekwane, Beukes and Isaac) have come together to form a secret activist alliance against the whites with a view to revolutionizing the unjust system of apartheid. Having silently coordinated this course for a specific period, they eventually opt for reaching out to the black community, by creating awareness, through handbills, of the existence of such a group, their achievement so far and their readiness to fight the course of freedom. The handbill reads:

'We bring a message... you will wonder that men and women would risk long terms of imprisonment to bring you this message. What kind of people do these things? The answer is simple. They are ordinary people who want freedom in this country... sent youth abroad to train as people's soldiers, technicians, administrators... we will fight back... To men who are oppressed freedom means many things... Give us back our country to rule for ourselves as we choose... Many ways to fight for freedom...'

The strong hostility or opposition towards the whites is indeed clear manifestation of their physical and psychological responses to the racial discrimination they are being subjected to by the whites. This is further noted in the thought of one of the protagonists, Beukes at the end of the narrative: 
Beukes stood by the side of the street in the early morning and thought, they have gone to war in the name of suffering of a people. What the enemy himself has created, these will become battle-grounds, and what we see now is only a tip of the ice-berg of resentment against an ignoble regime, the tortuous victims of hatred and humiliation. And those who persist in hatred and humiliation must prepare. Let them prepare hard and fast-they do not have long to wait. (pp. 180181)

Taking the activism of the three characters as wherein the violent revolution of the blacks is embodied, their motive then is considerable as an overt manifestation of 'introverted feeling' orientation in Jung's conception. According to Jung (1946, p. 44), introverted personality, as noted earlier on, is "normally characterized by a hesitant, reflective, retiring nature that keeps itself to itself, shrinks from objects, is always slightly on the defensive and prefers to hide behind mistrustful scrutiny". The element of strong solidarity by the oppressed blacks to channel an underground course to change their fortunes in the hand of their oppressors; the mindset by which Tekwane, Beukes and Isaac are characterised in the novel, points to a general trait of introverted personalities to reflect and react inwardly over their situations, and still keep to themselves while reacting to their conditions. This is because internal or subjective factors are the primary motivations by which they are being driven. On a specific note, in the 'feeling' orientation, Jung (1946, p. 638) states that such personality:

glides unheedingly over all subjects that do not fits in with his aim. It strives after inner intensity, for which the object serves at most as a stimulus. The depth of this feeling can only be guessed - it can never be clearly grasped. It makes people silent and difficult to access; it shrinks back like a violet from the brute nature of the object in order to feel the depths of the subject. It comes out with negative judgment or assumes an air of profound indifference as a means of defense.

On the forgoing, the inner intensity (of feeling) after which the personalities of the trio strive is considered to be the unconscious drive underlying their move to launch violent agitation against their oppressors even when they are aware of their inferiority, incapacity and the high risk involved in such an endeavour by a black in apartheid South Africa. In this regard, a Jungian analyst, Sharp (1987) notes that the motive of such personalities remains well hidden and are seldom outspoken or never reveal what they feel. This psychological state is evident in the Tekwane's insistence on not to speak out even in the face of life-threatening tortures. Rather than revealing such motivation behind their action, Sharp (1987, p. 75) observes further that "their subjective value generally exerts a positive secret on their surrounding". That is, these characters still muster much confidence on the positive outcome of their secret agitations in the long run. Hence, so long as they are being driven by this mindset, they would remain adamant to reveal anything about themselves. Their focus would be the object of their stimulus. In view of this, therefore, the socio-structural system of apartheid in which they find themselves serves fundamentally as the object-stimulus for their activism. 
Hence, because they have been overtaken by their unconscious realities, as shaped by apartheid regime, and is holding strong sway on their psyches, no amount of torture or threat would change their mindsets. It is a psychical structure that Ahmad regards as "Jamesonian political unconscious" which reverberates with apartheid system in South Africa (qtd. in Nwagbara, 2012, p. 115). The prisoner, Tekwane specifically typifies this; that is, rather than revealing what is innermost to them to his white interrogators amidst severe torture, he unconsciously shrinks from his object, like a snail to an object, which his mind sees as symbolic of heightened doom.

\section{CONCLUSION}

With particular emphasis on the centrality of characterisation to narratives, the study has deployed Jung's theory of psychological types, using two of the variables of personality analysis, to explain the probable psychological impulses behind the characterisation of La Guma's protagonists in the selected novels; a category of coloured South Africans who find themselves in a notorious regime that is marked with intense racial discrimination along colour lines, known as apartheid. Hence, the intensity of the attendant human right violation is critically presumed to have culminated in a psychic restructure which ultimately underscores the new personality formations being ascertained in the four characters - Micheal Adonis in A Walk in the Night and Tekwane, Beukes and Isaac in In the Fog of the Season's End. In other words, the realities of their environment cumulatively assume the hidden forces strongly holding sway on their personalities and/orbehaviours.

On the foregoing, thus, the ultimate revelation in the study is that the two extreme reactions are products of individual's innate tendencies, devoid of social or racial affiliations, bearing in mind that the two personality types have been ascertained in the characters of similar racial affiliation in the face of similar object-stimulus (of apartheid). In other words, in spite of the fact that all the characters are blacks, and are exposed to the same apartheid system, they have reacted diversely to the social injustice. This implies therefore that their reactions are apparently based on their individual's innate tendencies or idiosyncrasies which have only been ignited by objective or subjective forces of their most private anxieties and meanings held to culture and race. The validity of this claim can further be justified noting Jung's assertion that every individual possesses both the basic attitude types; therefore, a person is only identifiable with one personality type when, in the process of adaptation to his/her immediate realities, he develops or exhibits such personality orientation more than the other which is still potentially in such an individual.

\section{REFERENCES}

Astrid, S.(2005). Psychoanalysis and apartheid: The image and role of a psychiatrist in selected works of Lewis Nkosi. Lindy Stiebel and Liz Gunner (Ed.), Still Beating the Drum: Critical Perspectives on Lewis Nkosi (pp. 92-102). New York: Rodopi.

Azizah, N., \& Sudiran. (2015). A study on diglossia used by Helen Keller as the main characters in George Sullivan's novels "Helen Keller". Celtic: A Journal of English Language Teaching and Culture, 2 (3): pp. 1-18.

Babbie, R. E. \&Mouton, J. (2001). The practice is social research. Oxford: Oxford University Press. 
Garuba, I.O. (2020). Jung's Psychological Types and Characterisation in Alex Laguma's

Literary Works. Celtic: A Journal of Culture, English Language Teaching, Literature, \& Linguistics, 7(1), 44-56.

Bennett, A.\&Royle, N.(2014).Introduction to literature, criticism and theory $\left(3^{\text {rd }}\right.$ ed.).Harlow: Pearson.

Davenport, R.T. H. (1987).South Africa: A modern history.London: Palgrave Macmillan.

Denzin, N. K. \& Lincoln, Y. S. (1994). Handbook of qualitative research. Thousand Oaks: Sage.

De Laszlo, V. S. (ed.) (1959). The basic writings of C. G. Jung. New York: Modern Library Press.

Garuba, I. O. (2019). Alienation and character typology in African American and Native American narratives: A Jungian reading of the bluest eye and winter in the blood. Prague Journal of English Studies, 8(1): pp. 55-75.

Jung, C. G. (1946). Psychological types. London: Kegan Paul.

--- (1972). Two essays in analytical psychology. New York: Princeton University Press.

Kennedy, X. J. \&Gioia, D. (2007). Literature: An introduction to fiction, poetry, drama, and writing (Part 1 Fiction). New York: Longman.

Mowah, F. U. (1996). Psychology and African literature. Ibadan: Stirling-Horden.

Nwagbara, U. (2011).Arresting historical violence: Revolutionary aesthetics and Alex La

Guma's fiction. The Journal of Pan African Studies, 4 (3): pp. 14-130.

Ogbeide, V. O. (2014).Oases in the desert: Optimistic vision in Alex La Guma'sa walk in the night and a threefold cord. Research on Humanities and Social Sciences, 4 (7): pp. 115-121.

Patton, M. Q. \&Cochran, M. A guide to using qualitative research methodology. Medecins Sans Frontiers, 2002.

Pointer, F. H. (2011). A passion to liberate: La Guma's South African-Images of District Six. Trenton, NJ: Africa World Press.

Sharp, D. (1987). Personality types: Jung's model of typology. Toronto: Inner City Books.

Sommers-Flanagan, J.\&Sommers-Flanagan, R. (2004). Counselling and psychotherapy theories in context and practice: Skills, strategies and techniques $\left(2^{\text {nd }}\right.$ ed.). New Jersey: John Wiley \& Sons, Inc.

Stevick, P. (ed.). (1967).The theory of the novel. New York: The Free Press. 